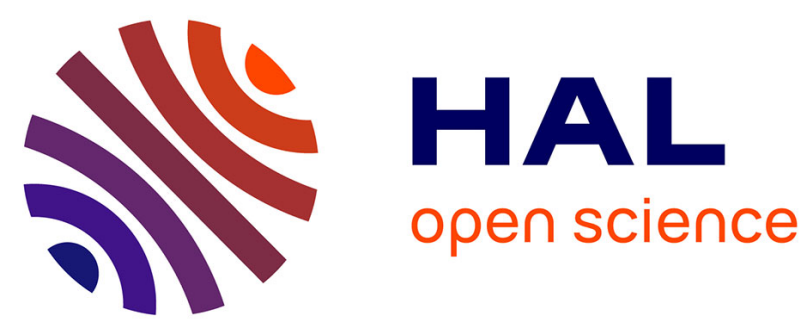

\title{
ON THE COLLAPSE BEHAVIOUR OF OIL RESERVOIR CHALK
}

Vincenzo de Gennaro, Pierre Delage, Grégoire Priol, Frederic Collin, Yu-Jun Cui

\section{- To cite this version:}

Vincenzo de Gennaro, Pierre Delage, Grégoire Priol, Frederic Collin, Yu-Jun Cui. ON THE COLLAPSE BEHAVIOUR OF OIL RESERVOIR CHALK. Geotechnique, 2004, 54 (6), pp.415-420. hal00137264

\section{HAL Id: hal-00137264 \\ https://hal.science/hal-00137264}

Submitted on 19 Mar 2007

HAL is a multi-disciplinary open access archive for the deposit and dissemination of scientific research documents, whether they are published or not. The documents may come from teaching and research institutions in France or abroad, or from public or private research centers.
L'archive ouverte pluridisciplinaire HAL, est destinée au dépôt et à la diffusion de documents scientifiques de niveau recherche, publiés ou non, émanant des établissements d'enseignement et de recherche français ou étrangers, des laboratoires publics ou privés. 


\section{ON THE COLLAPSE BEHAVIOUR OF OIL RESERVOIR CHALK}

De Gennaro, V. ${ }^{1 *}$, Delage, P. ${ }^{2}$, Priol, G. ${ }^{3}$, Collin, F. ${ }^{5}$, Cui, Y.-J. ${ }^{4}$

${ }^{1}$ Lecturer, Ecole Nationale des Ponts et Chaussées - LCPC, (CERMES, Institut Navier), Paris, France

${ }^{2}$ Professor, Ecole Nationale des Ponts et Chaussées - LCPC, (CERMES, Institut Navier), Paris, France

${ }^{3}$ Ph.D. student, Ecole Nationale des Ponts et Chaussées - LCPC, (CERMES, Institut Navier), Paris, France

${ }^{4}$ Assistant Professor, Ecole Nationale des Ponts et Chaussées - LCPC, (CERMES, Institut Navier), Paris, France

5 Postdoctoral Researcher FNRS, Université of Liège (Départment GéomaC), Liège, Belgium

Technical note submitted to Géotechnique : Paris, 24 December, 2003

Provisionally accepted 03 March 2004

Revised version 26 March 2004

* Corresponding author:

V. De Gennaro (Lecturer, Ph.D., C. Eng.)

CERMES, Ecole Nationale des Ponts et Chaussées - LCPC

6 et 8 avenue Blaise Pascal - Cité Descartes, Champs-sur-Marne 77455

Marne-la-Vallée Cedex 2 - FRANCE

Tél.: ++33 1641535 52, Fax: ++33 1641535 62, e-mail: degennar@cermes.enpc.fr 
Keywords: chalk, compaction, laboratory tests, offshore engineering, soft rocks, suction.

\section{INTRODUCTION}

In the last two decades, problems related to the seabed subsidence in the Ekofisk oilfield in the North Sea (about 10 m, Nagel, 2001) required a substantial revision in the production planning, as well as an important structural rehabilitation of the offshore platforms (Hermansen et al., 2000). Although it is now widely accepted that the main cause of the seabed settlement is the compaction of the $150 \mathrm{~m}$ thick layer of reservoir chalk $(\mathrm{n}=30-48 \%)$ located at a $3000 \mathrm{~m}$ depth below seafloor, the origin of the compaction is still an open issue. Early studies that related the compaction to increased effective stresses due to reservoir depletion (Johnson \& Rhett, 1986; Jones \& Leddra, 1989; Leddra et al., 1993) were soon questioned (Jones \& Mathiesen, 1993). The depletion phase (1971-1986) was followed in 1987 by an enhanced oil recovery procedure in which cold seawater was injected (waterflooding). Although pressure depletion was stalled, resulting in a constant effective stress, seabed subsidence continued.

Since the early eighties, the effect of the nature of the pore fluids, of their mutual interaction and of their interaction with the rock skeleton were examined to better interpret the origin of compaction (Newman, 1983; Monjoie et al., 1985; Piau \& Maury, 1994; Schroeder et al., 1998; Risnes et al., 2003). It was proposed to adopt a coupled hydro-mechanical framework taken from the mechanics of unsaturated soils (containing water and air as a non wetting fluid) and to adapt it to reservoir chalks (containing water and oil as a non wetting fluid) (Delage et al., 1996; Collin et al., 2002; De Gennaro et al., 2003). In this framework, it was demonstrated that the compaction induced by waterflooding bore strong similarities with the collapse of unsaturated soils when wetted under a constant load. In both cases, water was 
considered to located in menisci in the smaller pores close to the inter-grain contacts, remaining the largest available porosity to the non wetting fluid (air or oil).

In this framework, the oil-water suction $s_{o}$ was defined by $s_{o}=u_{o}-u_{w}\left(u_{o}\right.$ and $u_{w}$ being the oil and water pressures respectively). As in unsaturated soils (Coleman, 1962; Fredlund \& Morgenstern, 1977), two independent stress variables were considered, namely the oil-water suction $s_{o}$ and the mean net stress $p-u_{o}$. An extended experimental program including suction controlled oedometric and triaxial tests was developed from 1997 to 2003 within the framework of two European projects (Pasachalk1, 2001; Pasachalk2, 2004). Suction control was achieved by using both the oil overpressure (or axis translation) technique (Richards, 1941; Hilf, 1956) and the osmotic technique (Kassiff \& Benshalom, 1971; Delage et al., 1992). Among other things, the effects of physico-chemical chalk-water interactions as a complement of capillarity were evidenced. Finally, a constitutive "Pasachalk" model, derived from the Barcelona Basic Model (Alonso et al. 1990) with time effects added, was adapted to reservoir chalks and successfully used in reservoir simulations (Charlier et al., 2002; Collin et al., 2002).

In this note, some results of oedometer tests carried out on chalk samples under constant (oil-water) suction are presented. Particular emphasis is given to the effect of suction on the compression behaviour. Collapse due to waterflooding (i.e. decreasing the oil-water suction by replacing oil by water) under a constant load is also presented and discussed.

\section{TESTED MATERIAL}

Blocks of an outcrop chalk from Belgium called "Lixhe chalk", corresponding to the same geological layer than the Ekofisk reservoir chalk (Hod formation of the Upper Campanian level, Cretaceous period) were used in this study (Schroeder, 2002). 
SEM observation highlighted remains of coccolithes (skeletal debris of unicellular algae) which are present in small plates of about 1 to 10 microns dimensions (Fig. 1). Between the calcite grains, the voids (dimensions 1 to 5 microns) represent about half of the total volume, with an average porosity of about $40 \%$. This value was corroborated by a series of mercury intrusion porosimetry (MIP) tests that characterised a quite well defined population of large pores with an average entrance radius of about $0.37 \mu \mathrm{m}$ (Fig. 2). In the natural deposit, voids are filled with water in chemical equilibrium with the chalk, saturated in $\mathrm{CaCO}_{3}$. In the oil reservoir, chalk was initially filled by water a long time ago (35 millions years for Cretaceous chalks) and oil has afterwards infiltrated part of the pore space, expelling part of the water. Constant head permeability measurements (Pasachalk1, 2001) gave a value of intrinsic permeability $K$ of about $1 \times 10^{-14} \mathrm{~m}^{2}$ (corresponding to water and oil permeability respectively equal to $k_{\text {water }} \cong 1 \times 10^{-8} \mathrm{~ms}^{-1}, k_{\text {oil }} \cong 7 \times 10^{-9} \mathrm{~ms}^{-1}$ ).

A non polar and non toxic immiscible organic liquid called Soltrol 170 ${ }^{\circledR}$ (C12-C14 isoalkanes, Phillips Petroleum Co.) was used in this study to simulate oil. Soltrol $170^{\circledR}$ has also been selected for its very low solubility in water $\left(<<1 \mathrm{mg} / \mathrm{l}\right.$ at $\left.20^{\circ} \mathrm{C}\right)$ and very low volatility in air $\left(<<4 \times 10^{-2} \mathrm{~mm}^{3} / \mathrm{h}\right.$ at $\left.20^{\circ} \mathrm{C}\right)$. Soltrol $170^{\circledR}$ has a dynamic viscosity $\eta_{o}=2.028 \mathrm{cP}$ and a density $\rho_{o}=0.78 \mathrm{Mg} \mathrm{m}^{-3}$.

\section{EXPERIMENTAL INVESTIGATION}

The pressure discontinuity $\left(u_{o}-u_{w}\right)$ through the interface separating the two immiscible fluids (oil and water) gives rise to the capillary pressure (Laplace, 1806; in Morrow, 1970), that depends on the fluid interfacial tension and on the pore geometry. In clayey soils, additional physico-chemical fluid-mineral interactions exist. Both capillary and physico-chemical interactions are included in the definition of a potential energy called suction (Statement of the advisory panel 1965). This concept is considered to be valid in multiphase chalk. 
The control of suction was accomplished using the osmotic technique (Delage et al., 1992; Dineen \& Burland, 1995; Cui \& Delage, 1996). This technique consists in putting the sample in contact with a regenerated cellulose semi-permeable membrane behind which a solution of large molecules of polyethylene glycol (PEG) is circulated. Since the large PEG molecules cannot go through the semi-permeable membrane, an osmotic suction that increases with the PEG concentration is imposed on the sample through the membrane. Note that direct suction measurements carried out by Dineen \& Burland (1995) using the IC suction sensor (Ridley \& Burland, 1993) on samples in which the suction was osmotically imposed showed some deviations from the standard calibration of Williams \& Shaykewich (1969).

Some preliminary tests showed an excellent behaviour of the semi-permeable membrane when put in contact with Soltrol, with no apparent chemical reaction, no membrane damage and no resulting PEG leaks through the membrane. This was confirmed by careful examination made on the sample at the end of the tests, where no evidence of PEG infiltration (PEG infiltration in samples due to membrane breakdown are clearly apparent) was observed. The validity of the osmotic technique was particularly interesting in the case of oedometer testing, where the use of the osmotic technique is easier than that of the overpressure technique. Due to the difficulty of a simultaneous direct measurement of suction, the Williams \& Shaykewich (1969) calibration curve was used. This will probably result in an uncertainty at high suction levels, estimated at a maximum value of about $200 \mathrm{kPa}$ when considering the Dineen \& Burland (1995) measurements for suction values ranging between 0 $\mathrm{MPa}$ and 1.5 MPa. However, as will seen further on, the range of this uncertainty will not significantly affect the conclusions regarding suction effects on the compression behaviour of the chalk. 


\section{Sample preparation}

Chalk samples were cored from a block of chalk and then shaped on a lathe at the required size. Samples of about $50 \mathrm{~mm}$ diameter and $15 \mathrm{~mm}$ high were used for the oedometer tests (Table 1). For the retention tests, samples had a diameter of about $20 \mathrm{~mm}$ and their height ranged between 20 to $25 \mathrm{~mm}$ (De Gennaro et al., 2003). All the samples were oven dried at $105^{\circ} \mathrm{C}$, put under vacuum (approximately $-94 \mathrm{kPa}$ for 24 hours) and oil saturated under vacuum. The oil saturated state is to be related to a "dry" state of the chalk (with no water inside) with very high values of suction $s_{0}$.

Subsequent wetting down to controlled values of suction was made using the osmotic technique. Samples full of oil were inserted in a cylinder-shaped semi permeable membrane that was subsequently plunged in a PEG solution at the desired concentration (see Cui \& Delage, 1996). When doing so, a good contact between the membrane and the sample should be ensured. Due to the higher surface tension of water as compared to that of oil, water coming through the membrane progressively infiltrated the sample, giving rise to oil expulsion out of the sample. Visual observation showed that the expelled oil remained inside the membrane. This technique of imposing a suction when no stress application is required appeared quite convenient and inexpensive to treat many samples at the same time. Note that the infiltration of water in an oil saturated chalk is comparable to the waterflooding carried out in the oil reservoir chalk to enhance oil recovery.

\section{Retention properties of Lixhe chalk}

The wetting path of the retention curve of the Lixhe chalk containing oil and water is presented in Fig. 3 in a $\log s_{o}: S_{r w}$ diagram, where $S_{r w}$ is the degree of saturation in water. At high suctions $\left(s_{o}\right.$ higher than $0.5 \mathrm{MPa}$ ), large changes in suction induce small changes in expelled oil volume, whereas same suction changes at lower suction involves significantly 
larger expelled volume, leading to a residual degree of saturation in water of $70 \%$ (average) at zero suction.

This high residual degree of saturation in water shows the high water wettability of this chalk. Similar data are used in the Amott quantification of water wettability of reservoir rocks (Amott, 1959). Other North Sea chalks, like for instance in the Valhall oilfield (Andersen et al. 1992), present a hydrophobic behaviour. The origin of such a behaviour can be either adsorption of organic molecules along the coccolithe surfaces, due to the contact that occurred between oil and chalk minerals during a very long period of time of the reservoir history at elevated temperature (between $130{ }^{\circ} \mathrm{C}$ and $150{ }^{\circ} \mathrm{C}$ ) and pore pressure $(44.5 \mathrm{MPa}$ at 2400 m depth), or surface alteration due to oil-based drilling mud. It is most probable that the degree of wettability or non wettability to water of chalks is of utmost importance in the coupled hydro-mechanic behaviour of chalks.

\section{Suction controlled oedometer}

The samples were tested in the osmotic oedometer cell presented in Fig. 4. In this device, the bottom of the sample is in contact with a semi-permeable membrane below which a solution of polyethylene glycol (PEG) is circulated (Kassiff \& Benshalom, 1971; Delage et al., 1992). Water exchanges through the membrane are monitored through visual observation of the water level in the graduated tube placed in the bottle that contains the PEG solution. Water exchanges were in general very slow and it was observed that a period of time of about 15 days was necessary to reach equilibrium after imposing the desired suction.

In order to reach the desired net vertical stress, the sample was loaded using a high pressure oedometer frame with a double lever arm that allowed a maximum vertical stress of approximately $60 \mathrm{MPa}$ to be applied to a $50 \mathrm{~mm}$ diameter sample (Marcial et al., 2002). A 
standard step loading procedure was adopted. At each stage, the stabilisation of the PEG level in the tube was checked.

\section{TEST RESULTS AND DISCUSSION}

Figure 5 shows the results of 4 compression tests performed on chalk samples submitted to various oil-water suctions, namely: 0.1, 0.4 MPa (Fig. 5(a)) and 0.8 MPa and dry sample (Fig. 5(b)). Due to the overall importance of the initial void ratio on the compression behaviour, compression curves have been grouped according to their initial void ratio to facilitate comparisons. Data of samples with higher initial void ratios $(0.715$ at $0.1 \mathrm{MPa}$ and 0.702 at $0.4 \mathrm{MPa}$ ) are presented in Fig. 5(a) and that with lower void ratios (0.665 at $0.8 \mathrm{MPa}$ and 0.649 in dry state) in Fig. 5(b). All samples were loaded up to $10 \mathrm{MPa}$, submitted to an unloading-reloading cycle, and subsequently loaded up to a maximum vertical stress which was selected depending on the suction applied (20 MPa for the sample at $s_{o}=0.1 \mathrm{MPa}$, 30 $\mathrm{MPa}$ for the sample at $s_{o}=0.4 \mathrm{MPa}, 40 \mathrm{MPa}$ for the sample at $s_{o}=0.8 \mathrm{MPa}$ and for the dry sample). The corresponding void ratio was calculated from the volumetric strain obtained after 24 hours of applied constant loading.

The initial water saturation degrees $\left(S_{r w}\right)$ of the samples can reasonably be estimated from the retention curve of Fig. 3, giving respectively $S_{r w}=50 \%, 20 \%$ and $10 \%$, for the samples at $0.1,0.4$ and $0.8 \mathrm{MPa}$ respectively.

It can be observed in Fig. 5 that the yield stress (i.e. the maximum past consolidation stress) increases with increasing suction, i.e. with lower degrees of saturation in water $\left(S_{r w}\right)$. These results are in accordance with well established results showing a higher yield stress observed on chalk full of oil as compared to chalk full of water (Schroeder et al., 1998; Delage et al., 1996). They are also compatible with the water weakening effect. However, the results of Fig. 5 complete these observations by also accounting for the gradual effect of 
partial saturation in both fluids under a controlled suction. In this regard, the change in yield stress with suction is compatible with the conclusions drawn on unsaturated soils by Alonso et al. (1987 and 1990) and that founded the notion of a LC (Loading Collapse) curve. Note that, the results of the four tests presented here cannot be plotted together to determine a LC curve because of the effects of the change in void ratios, and increased density having also a significant effect on the yield stress. However, unlike in unsaturated soils, the slope in the plastic zone does not appear to be suction dependent. Conversely, like in unsaturated soils, the elastic response investigated by the unloading-reloading sequences, does not show any significant suction effect.

The collapse phenomenon of an oil saturated chalk sample due to waterflooding has been investigated in the framework of unsaturated soil mechanics by infiltration of water under a vertical load of $10 \mathrm{MPa}$, as shown in Fig. 6. In this test, the initial (theoretically) infinite oil-water suction was reduced to zero. In the absence of an available water saturated compression test at the same initial void ratio, a test at low suction ( $0.1 \mathrm{MPa}$ ) has been plotted together with the collapse test. As mentioned earlier, the initial degree of water saturation of this sample is about $5 \%$, as compared to the average value of $70 \%$ observed on samples saturated under a zero suction (see Fig. 3).

Water was infiltrated using the same system that allowed to circulate PEG solutions during suction controlled tests (Fig. 4). Thus, the circulation of pure water at the bottom of the chalk sample was ensured by the peristaltic pump shown in Fig. 4. However, with respect to the apparatus layout shown in the same figure, neither PEG solution nor cellulotic semipermeable membrane were necessary. The final point in Fig. 6 (point B) has been obtained after one week of continuous water circulation, and defines a total decrease of 0.025 in void ratio (path $\mathrm{AB}$ ). This variation of the void ratio corresponds to a compressive volumetric strain of about $1.5 \%$. Some creep may also have affected this volume decrease (Ruddy et al., 
1989; De Gennaro et al., 2003). It is worth noting that the induced volumetric strain due to wetting results from a natural infiltration process, developing from the bottom to the top of the sample. Unlike in waterflooding, during which the soft rock is soaked by water injection under pressure and suction may attain negative values (i.e. $u_{w}>u_{o}$, forced imbibition) and the residual oil saturation, infiltration requires much more time to achieve the water saturation degree corresponding to the complete suction release down to zero (i.e. $\mathrm{S}_{\mathrm{rw}}$ of about $70 \%$ ). Consequently, it is believed that higher volumetric strain would have been induced if water was injected at constant pressure. Nevertheless, the collapse observed in Fig. 6 is significant and comparable to earlier data of Newman (1983) on chalk samples from Cora, Dan and Gorm North Sea oilfields. The comparison with the 0.1 MPa compression curve shows that the point $\mathrm{B}$ is not located on or below the $0.1 \mathrm{MPa}$ compression curve, as could have been expected referring to well established results in unsaturated soils as shown through the double oedometer approach of Jennings \& Knight (1957) and the state surface of Matyas \& Radhakrishna (1968). This difference is, however, often observed in natural soils and is not surprising in this natural chalk.

In unsaturated soils, collapse is interpreted as a breakdown of an open porous metastable granular structure whose stability was ensured in the unsaturated state by capillary menisci at inter-granular contacts. Here, some questions arise due to the initial dry state of the chalk before oil saturation and to the existence of capillary menisci in such conditions. It seems more probable that the strongest inter-granular links existing in the oil saturated sample (which, if not capillary, have a significant physico-chemical component due to the high reactivity of carbonate) are progressively weakened by the infiltration of water through the smallest pores (i.e. at the inter-grain contacts) giving rise to collapse. 


\section{CONCLUSIONS}

An interpretation of the collapse mechanism induced by waterflooding in chalk reservoir rocks has been proposed in this note, based on the use of a framework taken from the mechanics of unsaturated soils. The relevant developments allowing for chalk mechanical testing under oil-water suction control have been described.

The osmotic technique has been used to control oil-water suction during retention tests following a wetting path. Its reliability in controlling suction in chalk has been verified. A series of suction controlled tests in the osmotic oedometer cell, performed on chalk samples having different relative saturation in oil and water, provided information on the mechanical behaviour of multiphase chalk under $K_{0}$ conditions and controlled suction. Due to the presence of two immiscible pore fluids (oil and water) of different surface tension properties, the volume change behaviour of oil reservoir chalk appears to present various similarities with that of unsaturated soils. Experimental results highlight the influence of oil-water suction on the mechanical response of the material.

As in unsaturated soils, the elastic behaviour of chalk is not affected by suction. Conversely, increasing suction induce an increase of the vertical stress at yielding. Suction decrease has been recognised to play a major role in interpreting the collapse due to wetting under constant load. This situation is comparable to that encountered in oilfields when waterflooding is used to enhance oil production. Water weakening effects and chalk compaction (collapse) seem likely to occur through the loss of strength of the inter-granular links existing in the oil saturated sample. The nature of these links includes both capillary and physico-chemical fluids-chalk interactions, and is well represented by the oil-water suction.

On the other hand, some differences can be mentioned in comparison with unsaturated soil behaviour, namely: (i) the lack of dependence of the slope of the virgin compressibility 
curve of the chalk on the suction values and (ii) the stress independence of the collapse phenomenon.

Time-dependent behaviour of oil reservoir chalks, including the analysis and elucidation of suction effects on creep, are currently the object of further research in this area.

\section{ACKNOWLEDGEMENTS}

The results presented in this note have been obtained within the framework of the European projects PASACHALK 1 (contract $n^{\circ}$ JOF3CT970033) and PASACHALK 2 (contract $n^{\circ}$ ENK6-2000-00089) carried out jointly by the University of Liege (Dpt. GeomaC, Belgium), the Ecole Nationale des Ponts et Chaussées (ENPC, Dpt. CERMES, Paris, France) and TotaFinaElf oil company (Drs. Ph. Keul and A. Onaisi). The collaboration of Dr. B. Chen during his Ph.D. stage at CERMES is also acknowledged.

\section{REFERENCES}

Amott, E. (1959). Observations relating to the wettability of porous rock. Trans. AIME 216: 156-162.

Alonso, E.E., Gens A. \& Hight, D.W. (1987). Special problem soils. General Report, Proc. $9^{\text {th }}$ Europ. Conf. on Soil Mechanics and Found. Eng., vol. 3, Dublin : 1087-1146.

Alonso, E.E., Gens A. \& Josa A. (1990). A constitutive model for partially saturated soils. Geotechnique 40(3): 405-430.

Andersen, M. A. (1995). Petroleum Research in North Sea Chalk. Public. RF-Rogaland Research \& JCR IV - Stavanger, Norway: 174 pp.

Bishop, A.W. \& Donald, I.B. (1961). The experimental study of partly saturated soil in the triaxial apparatus. Proc. $5^{\text {th }}$ Int. Conf. Soil Mech. and Found. Eng., vol. 1: 13-21. 
Charlier, R., Collin, F., Schroeder, Ch., Illing, P., Delage, P., Cui, Y.-J., \& De Gennaro, V. (2002). Constitutive modeling of chalk - application to waterflooding. Proc. 2nd Biot Conference, Grenoble (France) : 359 - 366.

Coleman, J.D. (1962). Stress strain relations for partly saturated soils. Correspondence Géotechnique, 12 (4): 348-350.

Collin, F., Cui, Y.-J., Schroeder, Ch., \& Charlier, R. (2002). Mechanical behaviour of Lixhe chalk partly saturated by oil and water : experiment and modeling. Int. J. for Num. Anal. Meth. in Geomechanics, 26: 897-924.

Cui, Y. J. \& Delage, P. (1996). Yielding and plastic behaviour of an unsaturated compacted silt. Géotechnique, 46 (2): 291-311.

De Gennaro, V., Delage, P., Cui, Y.J., Schroeder, Ch. \& Collin, F. (2003) . Time-dependent behaviour of oil reservoir chalk: a multiphase approach. Soils and Foundations, 43 (4): $131-148$

Delage, P., Suraj De Silva, G.P.R. \& Vicol, T. (1992). Suction controlled testing of non saturated soils with an osmotic consolidometer. Proc. $7^{\text {th }}$ Int. Conf. On Expansive Soils, Dallas: 206-211.

Delage, P., Schroeder, Ch. \& Cui, Y.-J. (1996). Subsidence and capillary effects in chalk. Proc. Eurock 96, Turin: 1291 - 1298.

Delage, P., Howat, M. \& Cui Y.-J. (1998). The relationship between suction and swelling properties in a heavily compacted unsaturated clay. Engineering Geology (50)1-2: 31-48.

Dineen, K. \& Burland, J.B. (1995). A new approach to osmotically controlled oedometer testing. Proc. $1^{\text {st }}$ Conf. on Unsaturated Soils - UNSAT '95 vol. 2, Paris : 459-465.

Fredlund, D.G. \& Morgenstern, D.N. (1977). Stress state variables for unsaturated soils. J. Soil Mech. and Found. Eng., ASCE, GT5: 447-476. 
Hilf, J.W. (1956). An investigation on pore-water pressure in compacted cohesive soils. Tech. Memo. 654, US Bureau of reclamation, Design and Construction Div., Denver, USA.

Hermansen, H., Landa, G.H., Sylte, J.E. \& Thomas, L.K. (2000). Experiences after 10 years of waterflooding the Ekofisk Field, Norway. J. of Petroleum Science and Eng., 26: 11-18.

Jennings, J.E. \& Knight, K. (1957) . The additional settlement of foundations due to collapse of sandy soils on wetting. Proc. $4^{\text {th }}$ Int. Conf. on Soil Mechanics and Foundations Eng., vol. 1 : 316-319.

Johnson , J.P. \& Rhett, D.W. (1986). Compaction behaviour of Ekofisk chalk as a function of stress. Society of Petroleum Engineers, SPE15872 : 221-225.

Jones, M.E. \& Leddra, M.J. (1989) . Compaction and flow of porous rocks at depth. Proc. Int. Conf. Rock at Great Depth, Maury \& Formaintraux Eds., Balkema : 891-898.

Jones, M.E. \& Mathiesen, E. (1993) . Pore pressure change and compaction in North Sea chalk hydrocarbon reservoirs. Int. J. of Rock Mech. Min. Sci. \& Geomech. Abstr., 30 (7) : 1205-1208.

Kassif, G. \& Ben Shalom, A. (1971). Experimental relationship between swell pressure and suction. Géotechnique 21 (3): 245-255.

Leddra, M.J., Jones, M.E. \& Goldsmith, A.S. (1993) . Compaction and shear deformation of a weakly-cemented, high porosity sedimentary rock. Proc. Int. Conf. on the Engineering Geology of Weak Rock, Cripps et al. Eds., Balkema : 45-54.

Lord, J.A., Clayton, C.R.I. \& Mortimore, R.N. (2002) . Engineering in chalk. CIRIA Eds., 334 pp.

Marcial D., Delage P. \& Cui Y.J. 2002. On the high stress compression of bentonites. Canadian Geotechnical Journal 39, 812-820.

Matyas, E.L. \& Radhakrishna, H.S. (1968). Volume change characteristics of partially saturated soils. Géotechnique 18 (4): 432-448. 
Monjoie, A., Schroeder, Ch., Da Silva, F., Debande, G. Detiège, Cl., \& Poot, B. (1985). Characterisation and Inhibition of Chalks. North Sea Chalk Symposium, Stavanger, Norway.

Morrow, N.R. (1970). Physics and Thermodynamics of capillary. Industrial and Engineering Chemistry, 62 (6): 32-56.

Nagel, N. (2001). Ekofisk geomechanics monitoring. Int. Workshop on Geomechanics in Reservoir Simulation, IFP, Reuil-Malmaison, France.

Newman, G.H. (1983). The effect of water chemistry on the laboratory compression and permeability characteristics of some North Sea chalks. J. of Petroleum Eng.: 976-980.

Pasachalk1 (2001). Mechanical Behaviour of PArtially and Multiphase SAturated CHALKs Fluid-skeleton Interaction : Main Factor of Chalk Oil Reservoirs Compaction and Related Subsidence. Publishable Final report, European Joule III contract № JOF3CT970033: 80 pp.

Pasachalk2 (2004). Mechanical Behaviour of PArtially and Multiphase SAturated CHALKs Fluid-skeleton Interaction : Main Factor of Chalk Oil Reservoirs Compaction and Related Subsidence. Part 2. Publishable Final report, Energy, Environment and Sustainable Development Programme, contract Nº ENK6-2000-00089: in print.

Piau , J.M., \& Maury V. (1994). Mechanical effects of water injection on chalk reservoirs. Paper SPE/ISRM 28133, EUROCK 1994.

Richards, L.A. (1941). A pressure-membrane extraction apparatus for soil solution. Soil science, 51: 377-386.

Ridley, A.M. \& Burland, J.B. (1993). A new instrument for measurement of soil moisture suction. Géotechnique 43 (2): 321-324.

Risnes, R., Haghighi, H., Korsnes, R.I. \& Natvik, O. (2003) . Chalk-fluids interactions with glycol and brines. Tectonophysics, 370 : 213-226. 
Ruddy, I., Andersen, M.A., Pattillo, P.D., Bishlawi, M. \& Foged, N. (1989). Rock compressibility, compaction and subsidence in a high porosity chalk reservoir: a case study of Valhall Field. J. of Petroleum Technology, 41 (7): 741-746.

Schroeder, Ch., Bois, A.P., Maury, V. \& Halle, G. (1998). Water/chalk (or collapsible soil) interaction: Part II. Results of tests performed in laboratory on Lixhe chalk to calibrate water/chalk models. SPE/ISRM (SPE 47587) Eurock'98, Trondheim.

Schroeder, Ch. (2002). Du coccolithe au reservoir petrolier. Univ. of Liege, PhD thesis.

Williams, J. \& Shaykewich, C.F. (1969). An evaluation of polyethylene glycol PEG 6000 and PEG 20000 in the osmotic control of soil water matric potential. Can. Geotech. J., 102 (6): 394-398. 
Table 1. Physical properties of chalk samples (oedometric tests)

\begin{tabular}{llllllll}
\hline Sample & $\mathbf{D}(\mathbf{m m})$ & $\mathbf{H}(\mathbf{m m})$ & $\mathbf{W}_{\mathbf{s}}(\mathbf{g})$ & $\mathbf{W}_{\text {sat }}(\mathbf{g})$ & $\mathbf{S}_{\mathbf{r w}}(\mathbf{\%})$ & $\mathbf{e}_{\mathbf{o}}{ }^{(\mathbf{1})}$ & $\boldsymbol{s}_{\boldsymbol{o}}(\mathbf{M P a})$ \\
\hline 1 & 49.89 & 17.11 & 52.41 & 63.26 & 98.6 & 0.704 & Oil sat. \\
2 & 49.84 & 13.64 & 43.11 & - & - & 0.649 & Dry \\
3 & 49.91 & 13.46 & 42.23 & 50.47 & 98.3 & 0.665 & 0.8 \\
4 & 49.84 & 14.19 & 43.43 & 52.28 & 97.4 & 0.702 & 0.4 \\
5 & 49.47 & 12.51 & 37.43 & 45.31 & 98.7 & 0.715 & 0.1 \\
\hline (1) calculated with $\mathrm{G}_{\mathrm{s}}=2.71$ & & & & & &
\end{tabular}



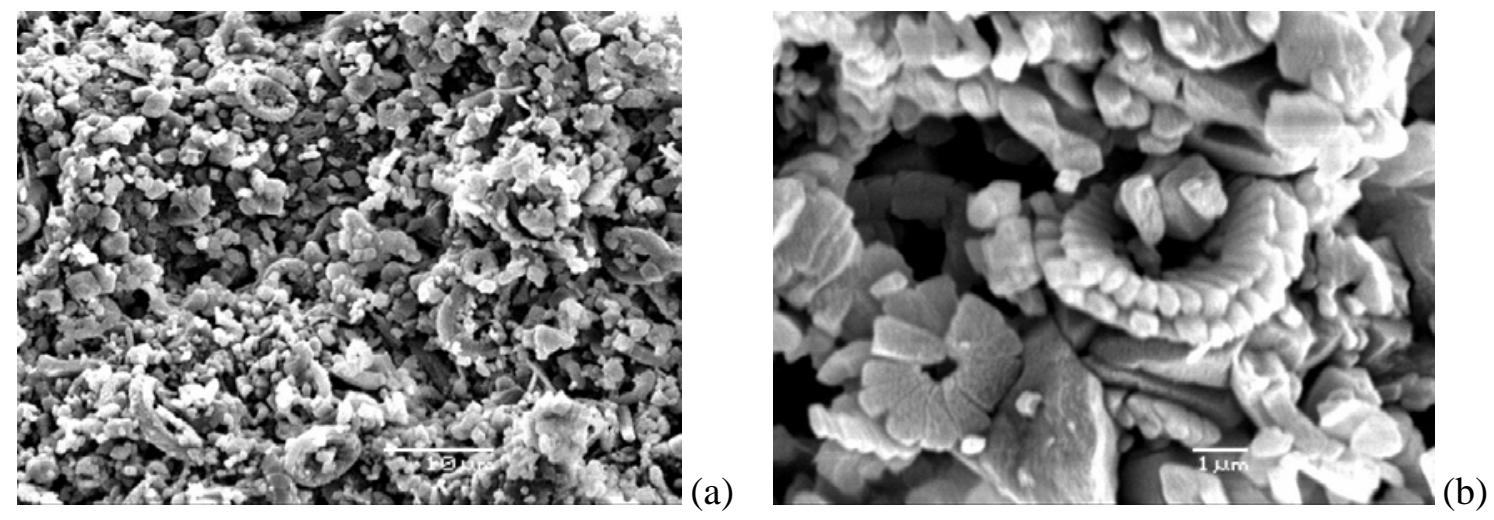

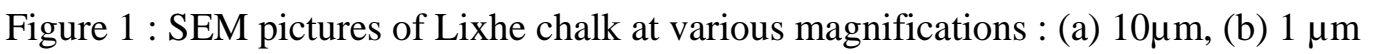

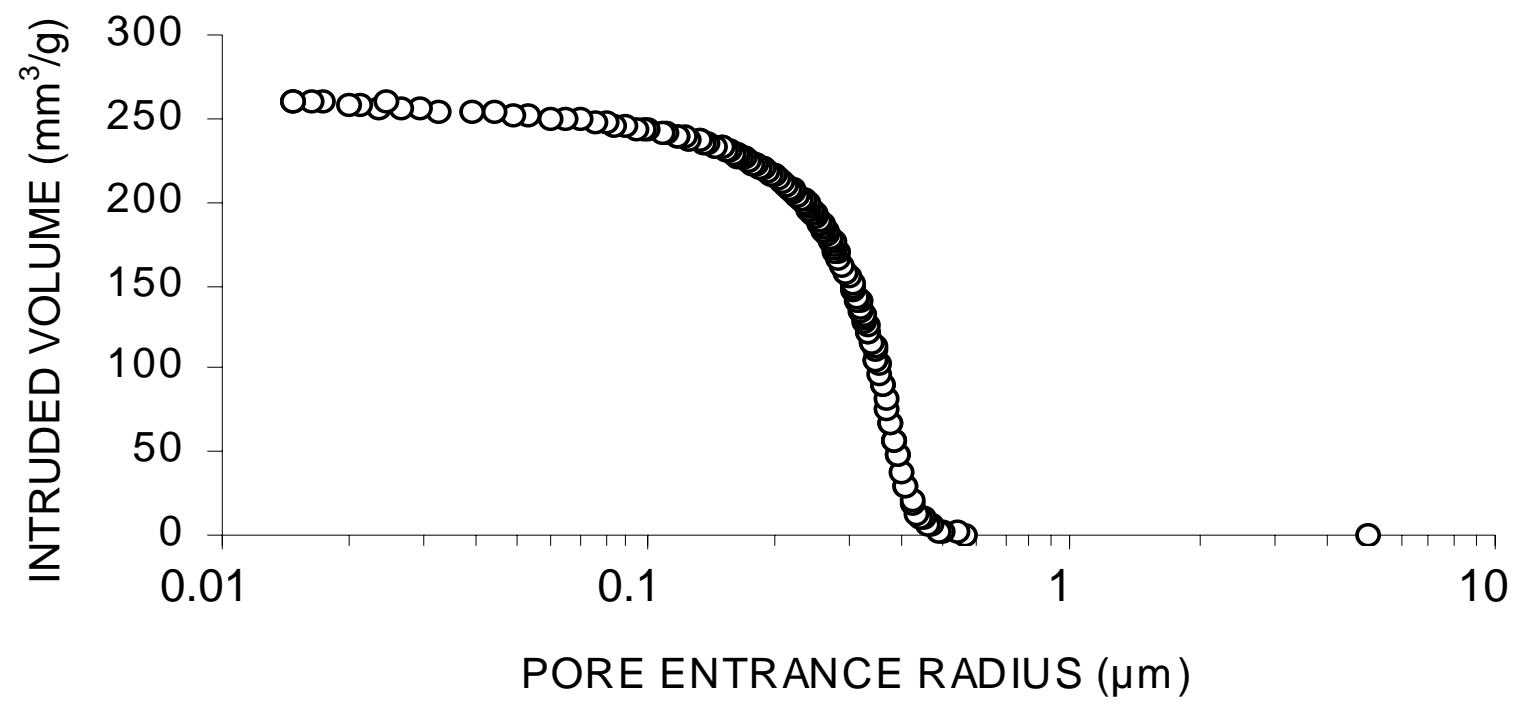

Figure 2 : Pore size distribution curve of Lixhe chalk 


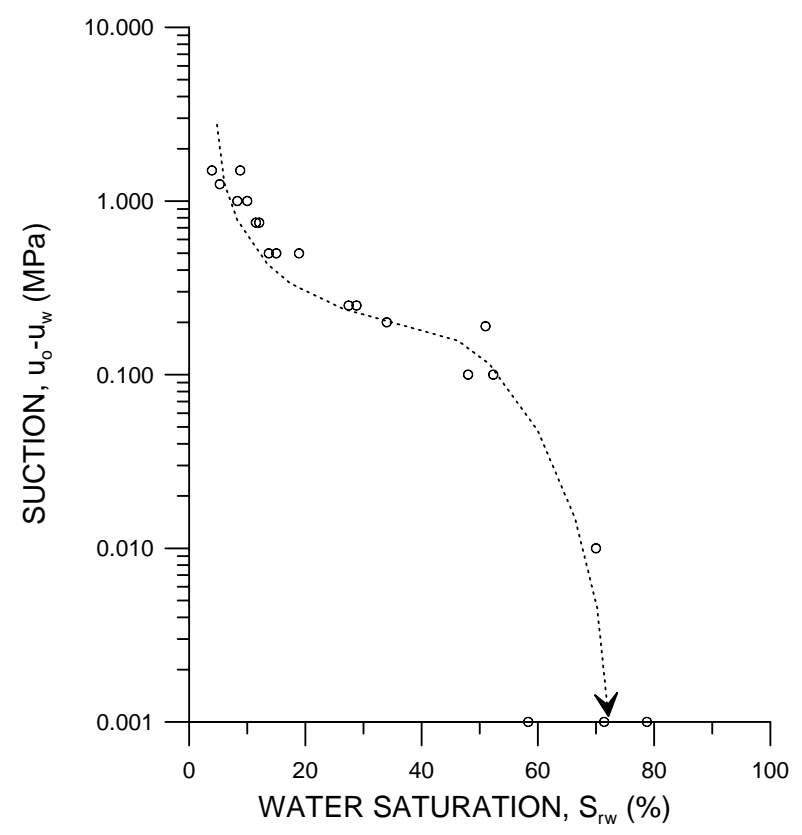

Figure 3 : Retention curve (wetting path) of Lixhe chalk

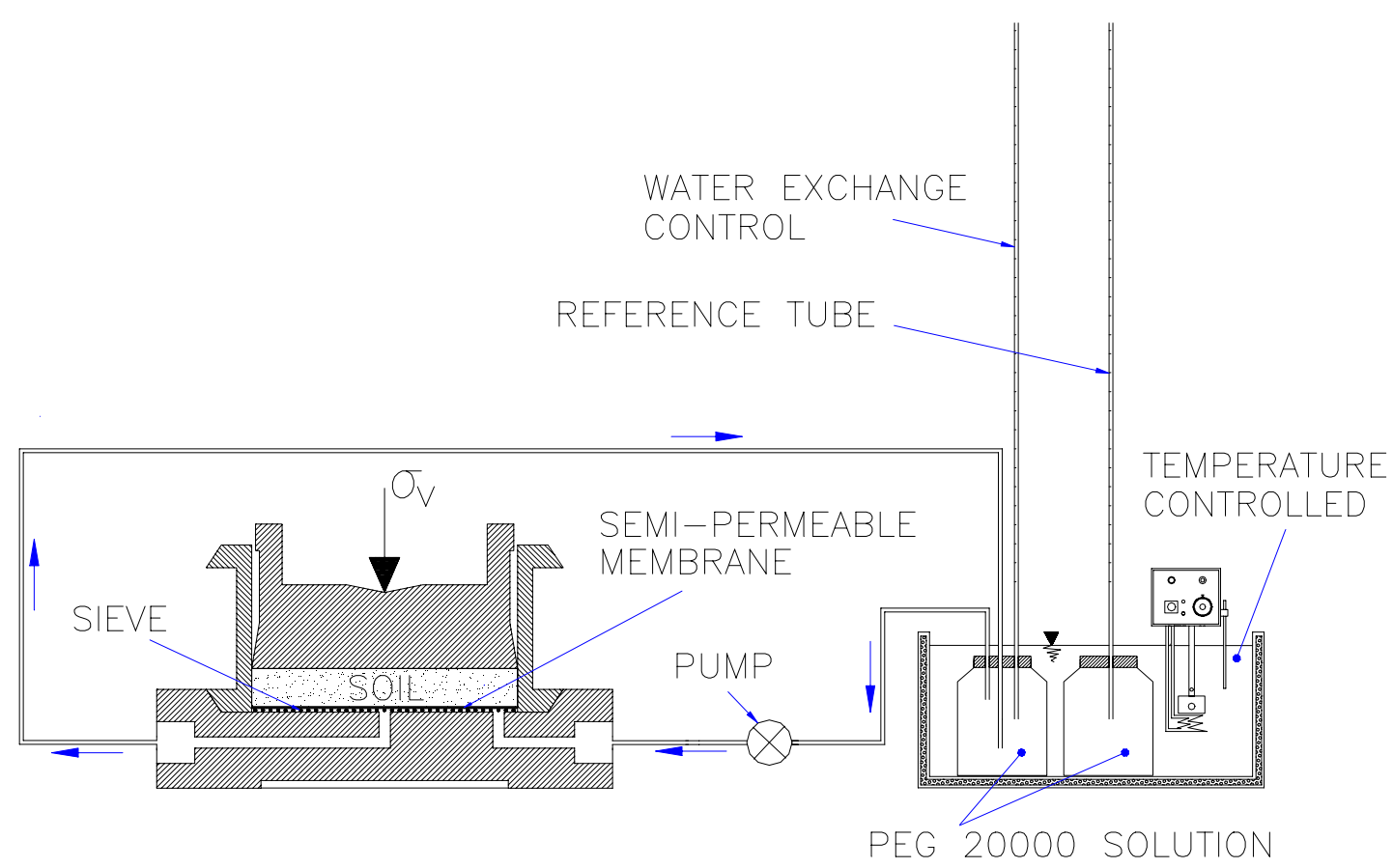

Figure 4 : Suction controlled oedometer 

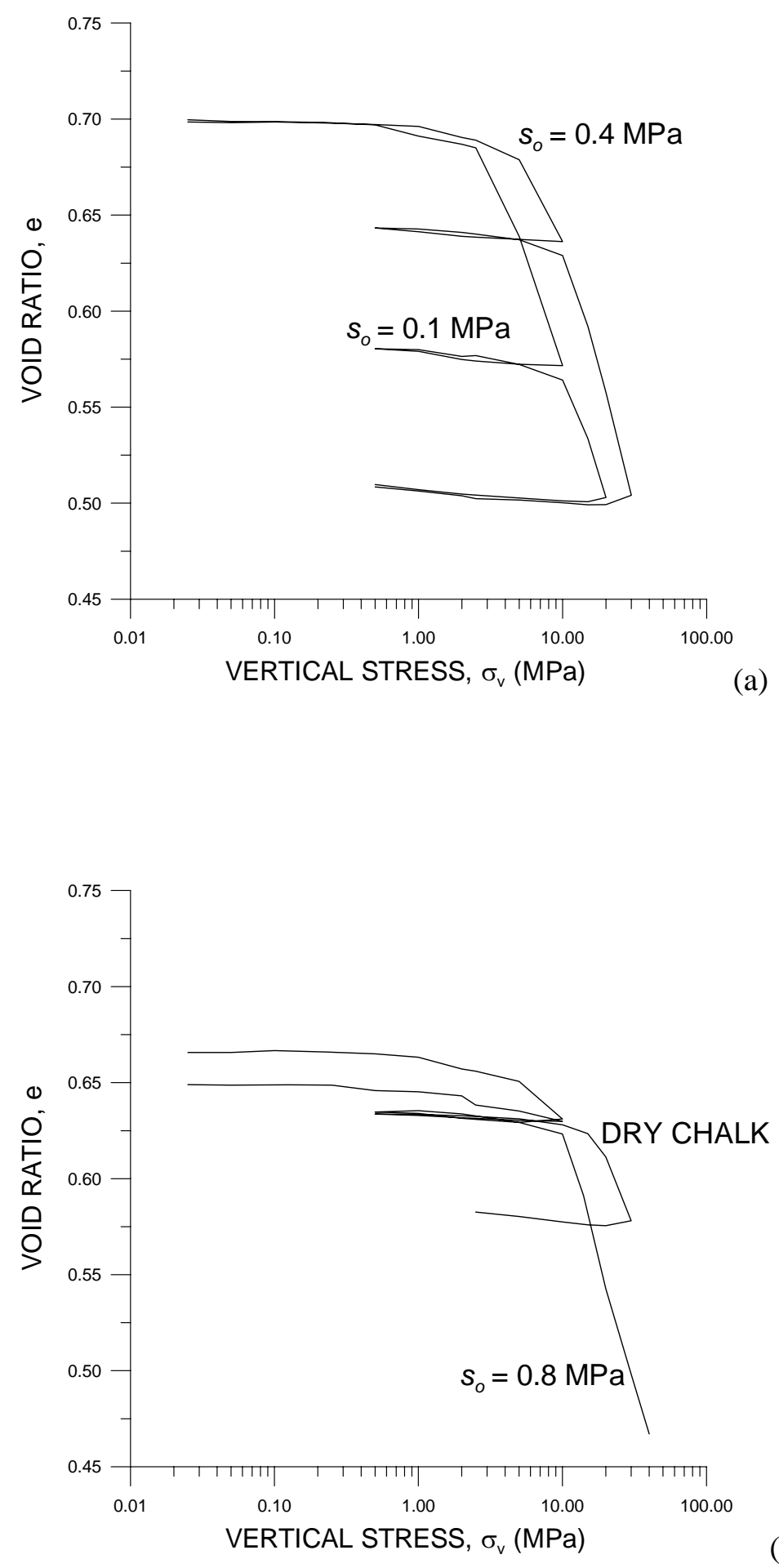

(b)

Figure 5 : Suction controlled oedometer tests on Lixhe chalk : (a) $\mathrm{e}_{\mathrm{o}} \cong 0.7$, (b) $\mathrm{e}_{\mathrm{o}} \cong 0.65$ 


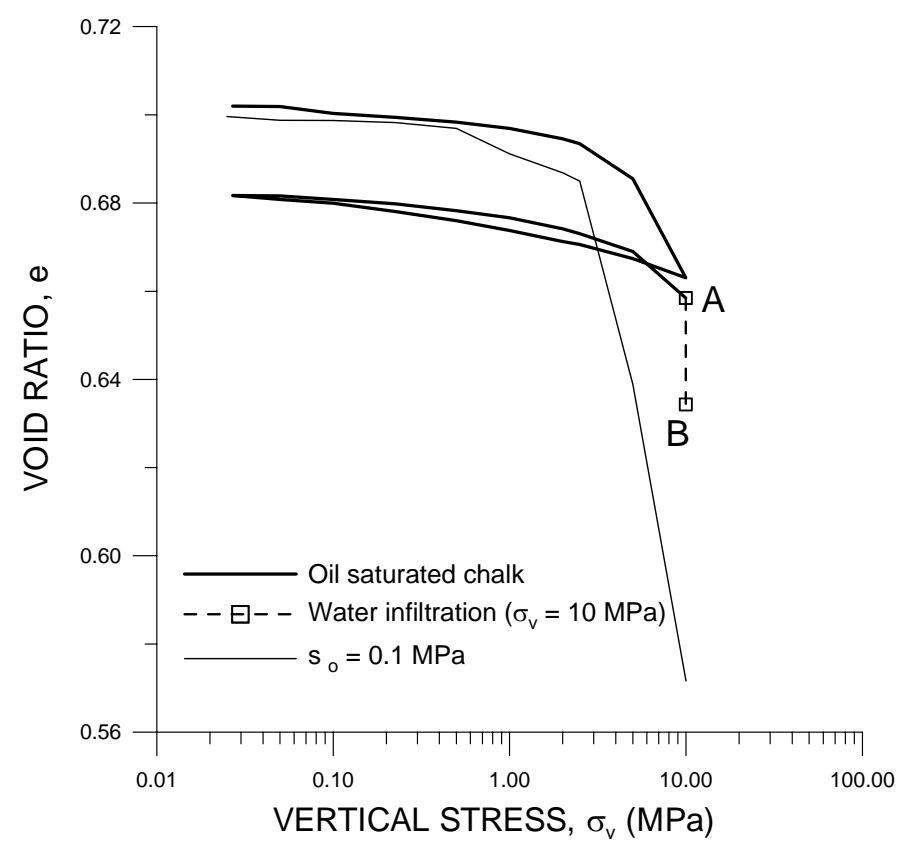

Figure 6 : Wetting induced collapse of oil saturated Lixhe chalk sample 